\title{
Biomass Productivity and Fatty Acid Composition of Chlorella lobophora V M Andreyeva, a Potential Feed Stock for Biodiesel Production
}

\author{
Kookal Santhoshkumar, Santhakumaran Prasanthkumar, Joseph George Ray* \\ Laboratory of Ecology \& Ecotechnology, School of Biosciences, Mahatma Gandhi University, Kottayam, India \\ Email: ${ }^{*}$ jgray@mgu.ac.in
}

Received 17 July 2015; accepted 27 September 2015; published 30 September 2015

Copyright $(2015$ by authors and Scientific Research Publishing Inc.

This work is licensed under the Creative Commons Attribution International License (CC BY). http://creativecommons.org/licenses/by/4.0/

(c) (i) Open Access

\begin{abstract}
Green algae represent the fastest producible source of biomass that has diverse uses as biofuel, food, feed-stocks and the like. The biomass is rich in oils, which can be used as biofuel and the cultivation may be used to purify water as well. Productivity and quality of algal biomass depends on species and strains as well as environmental conditions of growth. Therefore, identification of new species and strains as well as standardization of media composition and environmental conditions for optimum yield of specific products, especially oil has a high relevance in algal technological research. In this connection, biomass productivity and oil yield of a local strain of Chlorella lobophora in BBM and modified BBM media are compared. Chemical characterization of the oil and feasibility of biodiesel production from the extracted oil is also assessed. Biomass productivity and the lipid productivity of the alga in both the media are found to be significantly different $(P<0.05)$. Fatty acid profiling of the oil extracted from the dried algal biomass using GC-MS analysis reveals that Palmitic acid (16:0) and Oleic acid (18:1) are the major fatty acids and nutraceutically important fatty acids are also present. The oil can be effectively transesterified to methyl esters. FTIR spectroscopy confirms the quality of the biodiesel produced. As the potentials of this local algal strain for biomass production and oil yield is confirmed, further standardization of environment conditions for better oil yield and quality biomass production is progressing to optimize its value as globally competent nutraceutical and biofuel resource.
\end{abstract}

\section{Keywords}

Algal-Oil, Biofuel, Chlorella lobophora, Biomass Production

\footnotetext{
*Corresponding author.
}

How to cite this paper: Santhoshkumar, K., Prasanthkumar, S. and Ray, J.G. (2015) Biomass Productivity and Fatty Acid Composition of Chlorella lobophora V M Andreyeva, a Potential Feed Stock for Biodiesel Production. American Journal of Plant Sciences, 6, 2453-2460. http://dx.doi.org/10.4236/ajps.2015.615247 


\section{Introduction}

Biomass is considered to be one of the good alternatives for the current energy crisis. Algae are the fastest known producers of biomass per unit time, space and nutrient resources [1]. Rate of photosynthetic production in algae is higher than that of land plants [2]. Algae grow in a wide range of freshwater and wet soil habitats [3]. Highly ecologically favorable systems are available for economically viable production and cultivation of algae. Many algae have the ability to multiply and double their biomass from 3.5 hours to a full day [4].

Biomass is either liquefied directly to fuels or the oil extracted from oil-yielding biomass is esterified to potential fuels such as bio-diesel. Algal biomass is not only a potential source of high-value bio-oils but also yields chemicals, foods, food additives, therapeutic materials and animal feeds [5]. Moreover, algal culture in wastewaters always ensure the recovery of lost nutrients [6] and during the culture water is cleaned by means of phycoremediation. Among microalgae Chlorella species are proved to be highly industrially valuable for the production of lipids and biomasses [7], tolerant to high concentrations of $\mathrm{CO}_{2}$ [8], adaptable to various environmental conditions [9], useful in the treatment of industrial effluents [10] [11] and purification of waste-water systems [12].

However, biomass productivity and accumulation of specific compounds such as oil in algae depend upon the environment conditions and media compositions [13]. Environmental conditions that influence algal productivity and oil yield include duration and quality of sunlight, temperature, relative humidity, evaporation, precipitation, topography of lands, nutrients, carbon sources and water qualities [14]. Quality and quantity of biomass and oil yield of algae also depends on the kind of species and strains from local environments [15]. During in vitro culture of algae, the factors that influence productivity include media composition and cultural conditions [16]. Factors in the medium of growth have direct influence on specific product accumulations in algae; especially algal fatty acid composition within the biomass [17]. Oils and nutraceutically important pigment accumulations in algae depend on their media components and pH conditions [18] [19]. Some species of algae require specific growth media for high biomass productivity and sufficient lipid accumulation [20].

Among the specific growth media available for the mono-culturing of algae, Bold's Basal Medium (BBM) is one of the best general media, which is already demonstrated as a good medium for the culture of Chlorella sp., especially for high amount of total protein and chlorophyll pigments in the biomass [21]. Glucose enrichment in BBM under nitrogen limitation yields higher amount of lipids in Chlorella sorokiniana Shihira \& R. W. Krauss while no significant progress in the biomass productions [22]. In vitro experimental culture of specific algal species in specific media is therefore, inevitable to identify better species for biomass and other valuable resources, especially of oil yield from algae.

Screening of algal strains adapted to a wide range of environmental stress and the production of high biomass and lipids are of great importance in the current scenario. Several species of Chlorella from different climate zones are known for high quantity of lipids and biomass [23]. However, no reports are available on the biomass and oil-yield potentials of Chlorella lobophora, especially a local strain of the species that is quite common in bloomed water bodies of Kerala. The alga collected from a pond at Kasaragod District of Kerala is used in this study.

Major objectives of the present experimental study included comparison of in vitro biomass productivity of Chlorella lobophora in BBM and modified BBM; extract the algal oil from the biomass obtained from both media, chemical characterization of the oil, and feasibility of biodiesel production from the extracted oil. This is the pioneer report of biomass productivity and oil yield from Chlorella lobophora.

\section{Materials and Methods}

\subsection{Collection and Isolations of Algal Strain}

Freshwater sample containing local strains of Chlorella lobophora (Figure 1(a)) was collected in a sterilized one litre bottle from the bloomed freshwater pond of Ananthapura Temple (12 $\left.35^{\prime} 03.2^{\prime \prime N}, 74^{\circ} 58^{\prime} 55.4^{\prime \prime E}\right)$, Kasaragod District, Kerala, India during summer and rainy seasons. The $\mathrm{pH}$ of the water sample was measured and the alga collected was identified by using online algae database of Guri and Guri [24]. $50 \mathrm{~mL}$ of water sample were centrifuged at $6000 \mathrm{rpm}$ at room temperature $\left(27^{\circ} \mathrm{C}-30^{\circ} \mathrm{C}\right)$ for 5 minutes to concentrate the algal cells of the sampled water. High magnification digital compound microscope (Motic BA 310) was used for observation of the algal species. Serial dilution of water sample followed by micro capillary isolation method [25] and streak 


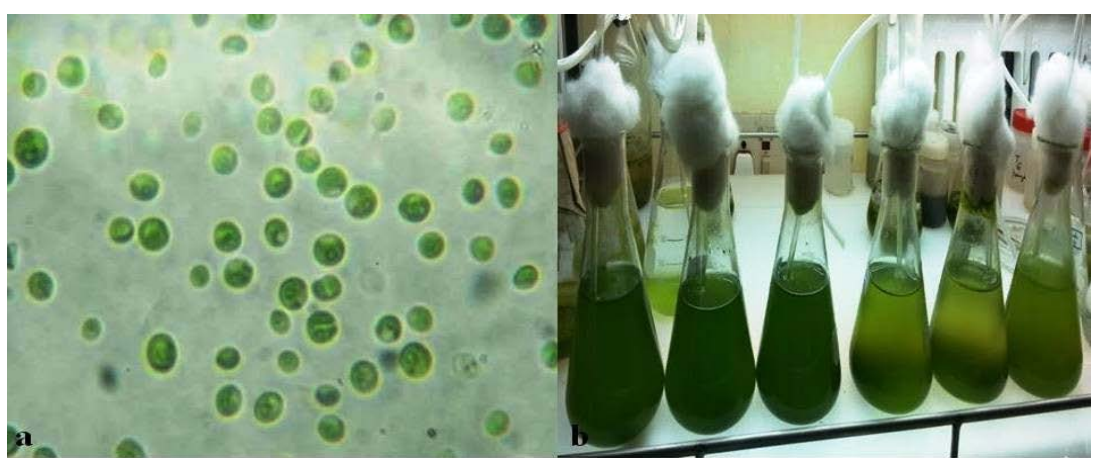

Figure 1. (a) Optical microscopic image of Chlorella lobophora; (b) Comparison of biomass production of alga in modified and normal Bold's Basal medium.

plate method were used for the isolation of the alga in pure form. The isolated strain was cultured in Bold's Basal Medium (BBM) at $\mathrm{pH}$ of 7.30. Pure culture of the strain in BBM is maintained in the algal culture facility centre in the Ecotechnology Laboratory, School of Biosciences, Mahatma Gandhi University.

\subsection{Comparison of Biomass Productivity of the Alga}

Cultures were carried out in one litre flasks using Bold's Basal Medium [26] and modified Bold's Basal Medium (Table 1) in triplicate (Figure 1(b)). All the culture vessels were incubated under controlled conditions of light (8000 Lux), temperature $\left(24^{\circ} \mathrm{C} \pm 2^{\circ} \mathrm{C}\right)$ and $\mathrm{pH}$ (7.30). Productivity was measured on completion of 30 days of growth. On completion of the incubation period the biomass was collected by centrifugation and the solid biomass was further air dried. Percentage increase of biomass per day per litre was calculated as productivity of algae, which is calculated by the formula

$$
\% \text { of Biomass productivity of algae/L/day }=\frac{\text { Final dry weight }}{\text { Initial dry weight } \times \text { total number of culturing days } \times \text { Vol. }} \times 100
$$

\subsection{Algal Oil Extraction}

Fresh algal biomass collected by centrifugation from the culture was oven dried (approximately at $40^{\circ} \mathrm{C}$ for 24 hrs). Ten gram of oven dried biomass was taken into a round bottom flask and added $100 \mathrm{~mL}$ of chloroform: methanol $(2: 1 \mathrm{v} / \mathrm{v})$ mixture into the biomass. The biomass was then kept soaked in the organic solvents at room temperature $\left(27^{\circ} \mathrm{C}-30^{\circ} \mathrm{C}\right)$ under continuous shaking at $150 \mathrm{rpm}$ for 4 hrs in a rotary shaker; afterwards the mixture was centrifuged at $6000 \mathrm{rpm}$ at room temperature for 5 minutes. Residual biomass was separated from the extract and then the oil along with the solvent was transferred in to a separating funnel. About $40 \mathrm{~mL}$ of distilled water was added to this mixture to separate the oil from the solvent. The oil got separated as an organic phase in bottom layers, which was then collected into a bottle. The separated biomass and the oil were made free of the solvent by using rotary evaporator.

The air dried residual biomass free of the solvent was further subjected to hot method of extraction for the collection of the remaining neutral lipids. The biomass was taken in to a Soxhlet extractor and extracted with 75 $\mathrm{mL}$ of hexane, refluxed under $70^{\circ} \mathrm{C}$ for 2 hours. The extracted oil components were collected and the oil was made free of the solvent by using rotary evaporator. Finally, the two extracted oil samples were mixed together to get the total oil extract.

\subsection{Chemical Characterization of Algal Oil}

$50 \mathrm{mg}$ of algal oil was saponified with $1 \mathrm{~mL}$ of saturated $\mathrm{KOH}-\mathrm{CH}_{3} \mathrm{OH}$ solution at $50^{\circ} \mathrm{C}$ for 10 minutes and then followed by methanolysis with $5 \% \mathrm{HCl}$ in methanol at $60^{\circ} \mathrm{C}$ for another 10 minutes in screw capped test tubes. The methyl fatty acids were separated by adding $2 \mathrm{~mL}$ of water into it and fatty acid phase was recovered. GC-MS (Agilent make 7890A-5975C) instrument was used for the fatty acid profiling. $1 \mathrm{~mL}$ of methyl fatty acid sample was injected to the GC column. Helium was used as carrier gas at flow rate of $54 \mathrm{~mL} / \mathrm{min}$. Chromatographic data was recorded and compared using Agilent data analysis software. 
Table 1. Chemical composition of bolds basal media and modified bolds basal media.

\begin{tabular}{|c|c|c|c|c|c|}
\hline SI. No. & Components & $\begin{array}{l}\text { Stock Solution } \\
\left(\mathrm{g} / \mathrm{L} \text { of } \mathrm{dH}_{2} \mathrm{O} \text { ) }\right.\end{array}$ & $\begin{array}{l}\text { Quantity Used } \\
\text { in BBM }\end{array}$ & $\begin{array}{l}\text { Quantity Used in } \\
\text { Modified BBM }\end{array}$ & $\begin{array}{l}\text { Concentration in } \\
\text { Final Medium (M) }\end{array}$ \\
\hline & Macronutrients & & & & \\
\hline 1 & $\mathrm{NaNO}_{3}$ & 25.00 & $10 \mathrm{~mL}$ & $10 \mathrm{~mL}$ & $2.94 \times 10^{-3}$ \\
\hline 2 & $\mathrm{CaCl}_{2} \cdot 2 \mathrm{H}_{2} \mathrm{O}$ & 2.50 & $10 \mathrm{~mL}$ & $10 \mathrm{~mL}$ & $1.70 \times 10^{-4}$ \\
\hline 3 & $\mathrm{MgSO}_{4} \cdot 7 \mathrm{H}_{2} \mathrm{O}$ & 7.50 & $10 \mathrm{~mL}$ & $10 \mathrm{~mL}$ & $3.04 \times 10^{-4}$ \\
\hline 4 & $\mathrm{~K}_{2} \mathrm{HPO}_{4}$ & 7.50 & $10 \mathrm{~mL}$ & $10 \mathrm{~mL}$ & $4.31 \times 10^{-4}$ \\
\hline 5 & $\mathrm{KH}_{2} \mathrm{PO}_{4}$ & 17.50 & $10 \mathrm{~mL}$ & $10 \mathrm{~mL}$ & $1.29 \times 10^{-3}$ \\
\hline \multirow[t]{2}{*}{6} & $\mathrm{NaCl}$ & 2.50 & $10 \mathrm{~mL}$ & $10 \mathrm{~mL}$ & $4.28 \times 10^{-4}$ \\
\hline & Alkaline EDTA Solution & & $1 \mathrm{~mL}$ & $1 \mathrm{~mL}$ & \\
\hline 7 & EDTA & 50.00 & & & $1.71 \times 10^{-4}$ \\
\hline \multirow[t]{2}{*}{8} & $\mathrm{KOH}$ & 31.00 & & & $5.53 \times 10^{-4}$ \\
\hline & Acidified Iron Solution & & $1 \mathrm{~mL}$ & $1 \mathrm{~mL}$ & \\
\hline 9 & $\mathrm{FeSO}_{4} \cdot 7 \mathrm{H}_{2} \mathrm{O}$ & 4.98 & & & $1.79 \times 10^{-5}$ \\
\hline \multirow[t]{2}{*}{10} & $\mathrm{H}_{2} \mathrm{SO}_{4}$ & $1 \mathrm{~mL}$ & & & \\
\hline & Boron Solution & & $1 \mathrm{~mL}$ & $1 \mathrm{~mL}$ & \\
\hline \multirow[t]{2}{*}{11} & $\mathrm{H}_{3} \mathrm{BO}_{3}$ & 11.42 & & & $1.85 \times 10^{-4}$ \\
\hline & Trace Metals Solution & & $1 \mathrm{~mL}$ & $1 \mathrm{~mL}$ & \\
\hline 12 & $\mathrm{ZnSO}_{4} \cdot 7 \mathrm{H}_{2} \mathrm{O}$ & 8.82 & & & $3.07 \times 10^{-5}$ \\
\hline 13 & $\mathrm{MnCl}_{2} \cdot 4 \mathrm{H}_{2} \mathrm{O}$ & 1.44 & & & $7.28 \times 10^{-6}$ \\
\hline 14 & $\mathrm{MoO}_{3}$ & 0.71 & & & $4.93 \times 10^{-6}$ \\
\hline 15 & $\mathrm{CuSO}_{4} \cdot 5 \mathrm{H}_{2} \mathrm{O}$ & 1.57 & & & $6.29 \times 10^{-6}$ \\
\hline \multirow[t]{2}{*}{16} & $\mathrm{Co}\left(\mathrm{NO}_{3}\right)_{2} \cdot 6 \mathrm{H}_{2} \mathrm{O}$ & 0.49 & & & $1.68 \times 10^{-6}$ \\
\hline & Fertilizer Solution & & & & \\
\hline 17 & Urea & 100 & Nil & $10 \mathrm{~mL}$ & $1.6 \times 10^{-2}$ \\
\hline 18 & $\mathrm{KCl}$ & 100 & Nil & $10 \mathrm{~mL}$ & $1.3 \times 10^{-2}$ \\
\hline 19 & $\mathrm{NH}_{4} \mathrm{PO}_{4}$ & 50 & Nil & $10 \mathrm{~mL}$ & $4.4 \times 10^{-3}$ \\
\hline
\end{tabular}

\subsection{Trans Esterification of Algal Oil and the Production of Biodiesel}

About $400 \mathrm{mg}$ of algal oil extracted were taken into a round bottom flask and mixed with $15 \mathrm{~mL}$ of methanolic sulphuric acid containing $2 \%$ sulphuric acid in methanol $(\mathrm{v} / \mathrm{v})$ and refluxed at $60^{\circ} \mathrm{C}$ for 4 hours with continuous shaking. The reaction was monitored by thin layer chromatography (TLC) with the solvent system, Hexane: Ethyl acetate/hexane: Toluene at the ratio of 9:1. The reaction was continued till the oil spot was disappeared on TLC plate. After the completion of reaction ( 2 - $4 \mathrm{hr}$ ), the contents were transferred to separating funnel and 25 $\mathrm{mL}$ water was added to it. The aqueous layer was extracted twice with ethyl acetate ( $25 \mathrm{~mL}$ each) and pooled the ethyl acetate layer. The extract was dried over anhydrous $\mathrm{Na}_{2} \mathrm{SO}_{4}$ and concentrated under vacuum.

\subsection{FTIR Analysis of Algal Biodiesel}

Thermo Scientific IS10 FTIR instrument was used for analyzing the algal biodiesel. The samples were analyzed in transmission mode in $400-4000 \mathrm{~cm}^{-1}$ wave number range. 


\subsection{Statistical Analysis}

Biomass productivity is presented as means \pm standard deviation of three replicates of algal samples in each medium; $t$-test is carried out to examine whether the difference in productivity of the species in two different media are significant.

\subsection{Calculation of Fatty Acid Composition of Algal Oil}

$$
\text { Percentage of oil in algae }(\%)=\frac{\text { Weight of oil }(g)}{\text { Weight of sample }(g)} \times 100
$$

\section{Result and Discussion}

\subsection{Biomass and Lipid Productivity of Alga}

Details of the biomass and lipid productivity as percentage increase of biomass per day per litre are given in Table 2. There was a significant difference in the yield of biomass and lipid of the alga between the two media. Chlorella species in BBM medium produces higher amount of protein and chlorophyll, compared to other culture media [21]. In the present investigation, modified Bold's Basal Medium with pH 7.30 showed higher biomass and lipid productivity of the alga than that in normal Bold's Basal Medium. The oil yield of alga grown in normal BBM was found to be $28 \%$ of the total dried algal biomass, while the yield in the modified BBM was $35 \%$. Statistical analysis has shown that biomass and lipid production of this alga in modified Bold's Basal Medium is significantly higher than that in the normal Bold's Basal Medium. Increase in biomass yield in accordance with change in medium compositions is already reported in another species of Chlorella [27]. However, in the current experiment using modified BBM, increase in yield of both biomass and lipid content observed for Chlorella lobophora in the modified medium. The nutrients added to modify the BBM are fertilizers such as urea, potassium chloride and ammonium phosphate, which are locally available and hence the modification is comparatively easier and affordable at commercial scales. Therefore, observations of this pilot experimental study on the suitability of a local strain of Chlorella lobophora as a potential crop for biomass and bio-oil has commercial feasibility. However, more experimentation of the same in diverse environmental conditions and nutrient conditions is required to standardize the specimen before commercial applications. Moreover, change in lipid quality in relation to environment conditions also need to be ascertained.

Chemical profile of the oil from this alga (Table 3) has shown that the major fatty acid component of the oil is Palmitic acid (C16:0), which accounts $27.2 \%$ of total fatty acids. Among all fatty acids, monosaturated fatty acids constitute $34.28 \%$ followed by $14.43 \%$ monounsaturated and $18 \%$ polyunsaturated fatty acids. Such an

Table 2. Biomass and lipid productivity in relation to environmental conditions in two different media.

\begin{tabular}{cccc}
\hline SI No. & Cultural Conditions & BBM & Modified BBM \\
\hline 1 & Quantity of the medium & $1 \mathrm{~L}$ & $1 \mathrm{~L}$ \\
2 & $\mathrm{pH}$ & 7.30 & 7.30 \\
3 & Temp in ${ }^{\circ} \mathrm{C}$ & $24 \pm 2$ & $24 \pm 2$ \\
4 & Light intensity (Lux) & 8000 & 8000 \\
5 & Duration of days & 30 & 30 \\
6 & Fresh weight of inoculums (mg) & 100 & 100 \\
7 & Dry weight of inoculums (mg) & 34 & 34 \\
8 & Dry weight of biomass after 30 days (mg) & $440.5 \pm 0.1$ & $660.63 \pm 2$ \\
9 & Growth of alga/L/day & $43 \%$ & $64.76 \%$ \\
10 & Lipid content & $28 \%$ & $35 \%$ \\
\hline
\end{tabular}


algal feed stock rich in mono-saturated and mono-unsaturated fatty acids are desirable for biodiesel production [28]. The most commonly used fatty acids for biodiesel productions in relation to quality are containing C16:0 and C18:1 fatty acids [29]. According to the American Society for Testing and Materials (ASTM) D6751 and European EN 14214 standards, monosaturated fatty acids are given preferences for the production of good quality biodiesels [30]. Therefore, Chlorella lobophora, which is capable of providing more of monosaturated fatty acids than unsaturated fatty acids, is a good option for biofuel production. Moreover, as $18 \%$ of its total fatty acid is constituted by the three important essential fatty acids, it has nutraceutical value as well.

\subsection{Trans Esterification of Algal Oil and FTIR Confirmation of Biodiesel}

The oil extracted from the alga could successfully be converted to biodiesel using acid catalyzed transesterification method. The IR spectra (Figure 2) peak $1742.08 \mathrm{~cm}^{-1}$ of transesterified algal oil was obtained from FT-IR spectrometer indicating the formation of biodiesel. As the characteristic peaks of esters in FTIR spectrum due to $\mathrm{C}=\mathrm{O}$ and $\mathrm{C}-\mathrm{O}$ bond around $1750-1730 \mathrm{~cm}^{-1}$ [31] are seen in the spectra, it became clear that the product is a mono alkyl ester, biodiesel. The spectrum of methyl esters is generally showing the wave range of $1750-1730$ $\mathrm{cm}^{-1}$ [32], which is generally absent in petro-diesel spectra [33].

\section{Table 3. GCMS profile of algal fatty acid.}

\begin{tabular}{ccc}
\hline SI. No. & Fatty acid profile & $\%$ in $1 \mathrm{ml}$ \\
\hline 1 & Myristic acid (C14:0) & 0.97 \\
2 & Palmitic acid (C16:0) & 27.22 \\
3 & Palmitoleic acid (C16:1 cis) & 2.13 \\
4 & Heptadecanoic acid (C17:0) & 2.72 \\
5 & Stearic acid (C18:0) & 3.37 \\
6 & Oleic acid (C18:1 cis) & 12.30 \\
7 & Linoleic acid (C18:2 cis) & 10.19 \\
9 & Linolenic acid (C18:3 cis) & 6.12 \\
\hline
\end{tabular}

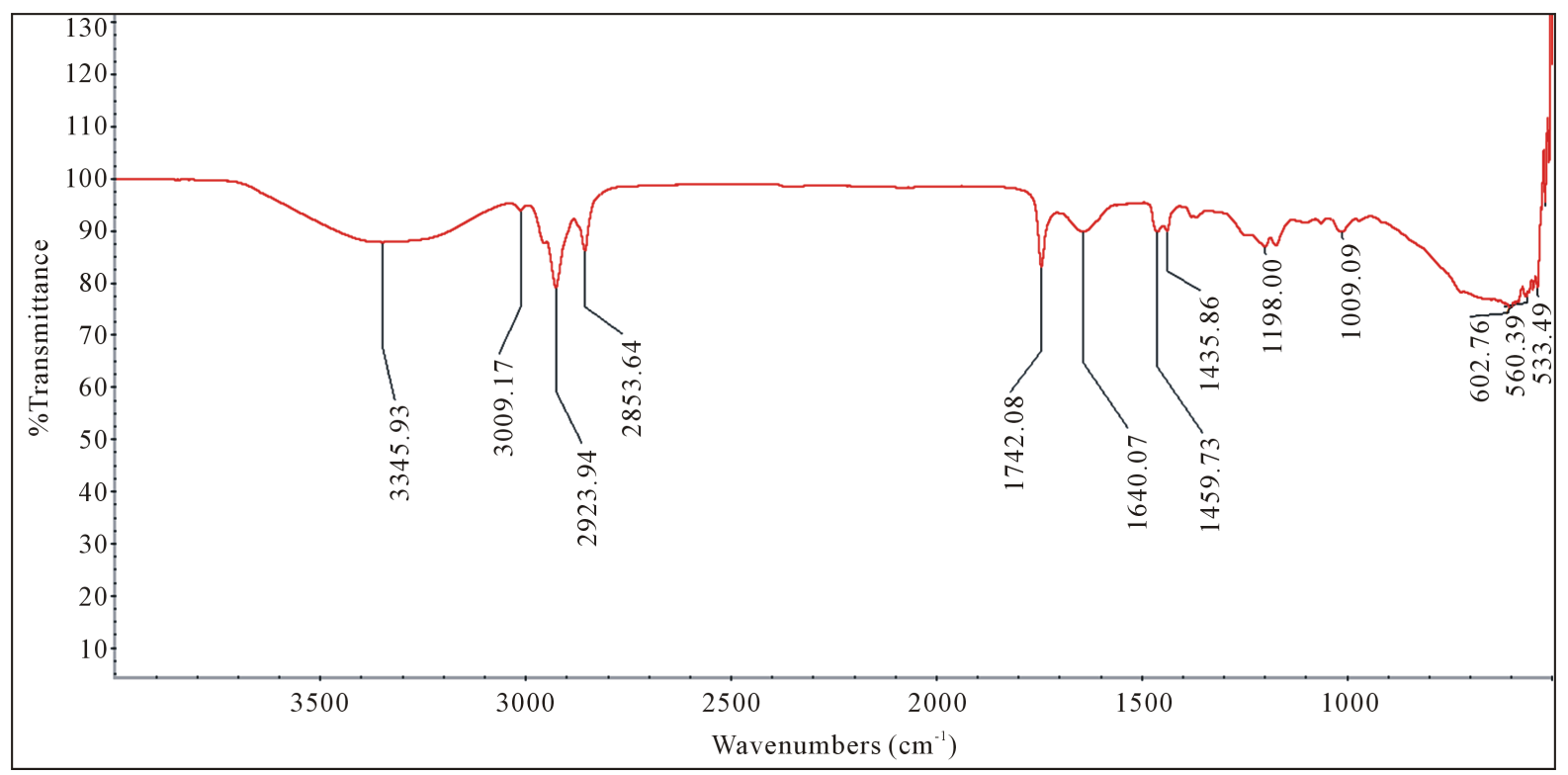

Figure 2. FTIR spectrum of algal biodiesel. 


\section{Conclusion}

For Chlorella lobophora, Bold's Basal Medium is found to be suitable for small scale production of the alga and also for maintaining culture stocks. Compared with BBM, modified Bold's Basal Medium with little higher NPK provided as commercially available chemical fertilizers is found to be a better medium for higher yield of biomass and lipid from the alga. Oil content of Chlorella lobophora is $28 \%$ and $35 \%$ of its dry biomass in the BBM and modified BBM respectively. Fatty acid composition of the oil in the alga has significant percentage of monosaturated and monounsaturated fatty acids, which is suitable for biodiesel production. In adition to the biofuel applications, the oil is nutraceutically important because of $18 \%$ of essential fatty acid in the oil. Therefore, the local strain of Chlorella lobophora is found to be a promising species of alga for nutraceutical and biofuel feedstock. Further explorations on lipid production potential of this alga in different media and under different cultural conditions are continuing. Moreover, oil composition in relation to different cultural conditions also is getting standardized.

\section{Acknowledgements}

Support extended by Dr. I. Ibnusaud Director, Institute for Intensive Research in Basic Sciences, Mahatma Gandhi University for FTIR analysis carried out at his laboratory is gratefully acknowledged.

\section{References}

[1] Campbell, M.N. (2008) Biodiesel : Algae as a Renewable Source for Liquid Fuel. Guelph Engineering Journal, 1, 2-7.

[2] Pirt, S.J. (1986) The Thermodynamic Efficiency (Quantum Demand) and Dynamics of Photosynthetic Growth. New Phytologist, 102, 3-37. http://dx.doi.org/10.1111/j.1469-8137.1986.tb00794.x http://www.soe.uoguelph.ca/webfiles/gej/articles/GEJ_001-002-007_Campbell_Biodiesel_from_Algae.pdf

[3] Ray, J.G. and Thomas, T.B. (2012) Ecology and Diversity of Green-Algae of Tropical Oxic Dystrstepts Soils in Relation to Different Soil Parameters and Vegetation. Research Journal of Soil Biology, 4, 42-68. http://dx.doi.org/10.3923/rjsb.2012.42.68

[4] Chisti, Y. (2007) Biodiesel from Micro Algae. Biotechnology advances, 25, 294-306. http://dx.doi.org/10.1016/j.biotechadv.2007.02.001

[5] Yamaguchi, K. (1997) Recent Advances in Microalgal Bioscience in Japan, with Special Reference to Utilization of Biomass and Metabolites: A Review. Journal of Applied Phycology, 8, 487-502. http://dx.doi.org/10.1007/BF02186327

[6] Chiu, S., Kao, C., Chen, T., Chang, Y., Kuo, C. and Lin, C. (2015) Cultivation of Microalgal Chlorella for Biomass and Lipid Production Using Wastewater as Nutrient Resource. Bioresource Technology, 184, 179-189. http://dx.doi.org/10.1016/j.biortech.2014.11.080

[7] Josephine, A., Niveditha, C., Radhika, A., Shali, A.B., Kumar, T.S., Dharani, G. and Kirubagaran, R. (2015) Analytical Evaluation of Different Carbon Sources and Growth Stimulators on the Biomass and Lipid Production of Chlorella vulgaris-Implications for Biofuels. Biomass and Bioenergy, 75, 170-179. http://dx.doi.org/10.1016/j.biombioe.2015.02.016

[8] Sung, K.D., Lee, J.S., Shin, C.S., Park, S.C. and Choi, M.J. (1999) $\mathrm{CO}_{2}$ Fixation by Chlorella sp. KR-1 and Its Cultural Characteristics. Bioresource Technology, 68, 269-273. http://dx.doi.org/10.1016/S0960-8524(98)00152-7

[9] Chu, H., Tan, X., Zhang, Y., Yang, L., Zhao, F. and Guo, J. (2015) Continuous Cultivation of Chlorella pyrenoidosa Using Anaerobic Digested Starch Processing Wastewater in the Outdoors. Bioresource Technology, 185, 40-48. http://dx.doi.org/10.1016/j.biortech.2015.02.030

[10] Krishna, A.R., Dev, L. and Thankamani, V. (2012) An Integrated Process for Industrial Effluent Treatment and Biodiesel Production Using Microalgae. Research in Biotechnology, 3, 47-60.

[11] Dalrymple, O.K., Halfhide, T., Udom, I., Gilles, B., Wolan, J., Zhang, Q. and Ergas, S. (2013) Wastewater Use in Algae Production for Generation of Renewable Resources: A Review and Preliminary Results. Aquatic Biosystems, 9, 2. http://dx.doi.org/10.1186/2046-9063-9-2 http://www.pubmedcentral.nih.gov/articlerender.fcgi?artid=3561657\&tool=pmcentrez\&rendertype=abstract

[12] Deviram, G., Pradeep, K.V. and Prasuna, R.G. (2011) Purification of Waste Water Using Algal Species. European Journal of Experimental Biology, 1, 216-222.

[13] Sun, Z., Zhou, Z., Gerken, H., Chen, F. and Liu, J. (2015) Screening and Characterization of Oleaginous Chlorella Strains and Exploration of Photoautotrophic Chlorella Protothecoides for Oil Production. Bioresource Technology, 184, 
53-62. http://dx.doi.org/10.1016/j.biortech.2014.09.054

[14] Sudhakar, K. and Premalatha, M. (2012) Theoretical Assessment of Algal Biomass Potential for Carbon Mitigation and Biofuel Production. Iranica Journal of Energy \& Environment, 3, 232-240.

http://www.ijee.net/Journal/ijee/vol3/no3/5.pdf http://dx.doi.org/10.5829/idosi.ijee.2012.03.03.3273

[15] Juneja, A., Ceballos, R. and Murthy, G. (2013) Effects of Environmental Factors and Nutrient Availability on the Biochemical Composition of Algae for Biofuels Production: A Review. Energies, 6, 4607-4638.

http://www.mdpi.com/1996-1073/6/9/4607/ http://dx.doi.org/10.3390/en6094607

[16] Takeshita, T., Ota, S., Yamazaki, T., Hirata, A. and Zachleder, V. (2014) Starch and Lipid Accumulation in Eight Strains of Six Chlorella Species under Comparatively High Light Intensity and Aeration Culture Conditions. Bioresource Technology, 158, 127-134. http://dx.doi.org/10.1016/j.biortech.2014.01.135

[17] Olofsson, M., Lamela, T., Nilsson, E., Bergé, J.P., del Pino, V., Uronen, P. and Legrand, C. (2012) Seasonal Variation of Lipids and Fatty Acids of the Microalgae Nannochloropsis oculata Grown in Outdoor Large-Scale Photobioreactors. Energies, 5, 1577-1592. http://dx.doi.org/10.3390/en5051577

[18] Kilham, S., Kreeger, D., Goulden, C. and Lynn, S. (1997) Effects of Nutrient Limitation on Biochemical Constituents of Ankistrodesmus falcatus. Freshwater Biology, 38, 591-596. http://dx.doi.org/10.1046/j.1365-2427.1997.00231.x http://www3.interscience.wiley.com/cgi-bin/fulltext?ID=119146803\&PLACEBO=IE.pdf\&mode=pdf

[19] Sharma, K.K., Schuhmann, H. and Schenk, P.M. (2012) High Lipid Induction in Microalgae for Biodiesel Production. Energies, 5, 1532-1553. http://dx.doi.org/10.3390/en5051532

[20] Mizuno, Y., Sato, A., Watanabe, K., Hirata, A., Takeshita, T., Ota, S., Sato, N., Zachleder, V., Tsuzuki, M. and Kawano, S. (2013) Sequential Accumulation of Starch and Lipid Induced by Sulfur Deficiency in Chlorella and Parachlorella Species. Bioresource Technology, 129, 150-155. http://dx.doi.org/10.1016/j.biortech.2012.11.030

[21] Sankar, M. and Ramasubramanian, V. (2012) Biomass Production of Commercial Algae Chlorella Vulgaris on Different Culture Media. E-Journal of Life Sciences, 1, 56-60.

https://www.academia.edu/5862956/Biomass_production_of_commercial_algae_Chlorella_vulgaris_on_different_cult ure_media

[22] Juntila, D.J., Bautista, M.A. and Monotilla, W. (2015) Biomass and Lipid Production of a Local Isolate Chlorella sorokiniana under Mixotrophic Growth Conditions. Bioresource Technology, 191, 3-6. http://linkinghub.elsevier.com/retrieve/pii/S0960852415004307

[23] Xu, J. and Hu, H. (2013) Screening High Oleaginous Chlorella Strains from Different Climate Zones. Bioresource Technology, 144, 637-643. http://dx.doi.org/10.1016/j.biortech.2013.07.029

[24] Guiry, M.D. and Guiry, G.M. (2015) Chlorella lobophora V.M Andreyeva. Worldwide Electronic Publications, National University of Ireland, Galway. http://www.algaebase.org/search/species/detail/?species_id=gdfb06b9e08b65a7f

[25] Stein, J.R. (1973) Handbook of Phycological Methods: Culture Methods and Growth Measurements. Cambridge University Press, Cambridge, 56-60.

[26] Andersen, R.A. (2005) Algal Culturing Techniques. Elsevier Academic Press, London, 578.

[27] Kobayashi, N., Noel, E.A., Barnes, A., Watson, A., Rosenberg, J.N., Erickson, G. and Oyler, G.A. (2013) Characterization of Three Chlorella sorokiniana Strains in Anaerobic Digested Effluent from Cattle Manure. Bioresource Technology, 150, 377-386. http://dx.doi.org/10.1016/j.biortech.2013.10.032

[28] Stansell, G.R., Gray, V.M. and Sym, S.D. (2012) Microalgal Fatty Acid Composition: Implications for Biodiesel Quality. Journal of Applied Phycology, 24, 791-801. http://dx.doi.org/10.1007/s10811-011-9696-x

[29] Knothe, G. (2005) Dependence of Biodiesel Fuel Properties on the Structure of Fatty Acid Alkyl Esters. Fuel Processing Technology, 86, 1059-1070. http://dx.doi.org/10.1016/j.fuproc.2004.11.002

[30] Knothe, G. (2008) “Designer” Biodiesel: Optimizing Fatty Ester Composition to Improve Fuel Properties. Energy and Fuels, 22, 1358-1364. http://dx.doi.org/10.1021/ef700639e

[31] Tahira, F., Hussain, S.T., Ali, S.D., Iqbal, Z. and Ahmad, W. (2012) Homogeneous Catalysis of High Free Fatty Acid Waste Cooking Oil to Fatty Acid Methyl Esters (Biodiesel). International Journal of Environment and Pollution, 1, 31-36.

[32] Mistry, B.B. (2009) A Handbook of Spectroscopic Data Chemistry (UV, IR, PMR, 13CNMR and Mass Spectroscopy). Oxford Book Company, Jaipur, 27-63.

[33] Patil, P.D., Gude, V.G., Mannarswamy, A., Deng, S., Cooke, P., Munson-McGee, S., Rhodes, I., Lammers, P. and Nirmalakhandan, N. (2011) Optimization of Direct Conversion of Wet Algae to Biodiesel under Supercritical Methanol Conditions. Bioresource Technology, 102, 118-122. http://dx.doi.org/10.1016/j.biortech.2010.06.031 